\title{
PARTICIPATORY GIS FOR SOIL CONSERVATION IN PHEWA WATERSHED OF NEPAL
}

\author{
Krishna Prasad Bhandari \\ Western Region Campus, Institute of Engineering, Tribhuvan University, Pokhara, Nepal \\ Email:bhandarikrishna@hotmail.com.
}

\section{Commission VIII, WG VIII/8}

KEY WORDS: Participatory Geographic information, Local Knowledge, Stakeholders, RUSLE, Soil erosion risk map

\begin{abstract}
Participatory Geographic Information Systems (PGIS) can integrate participatory methodologies with geo-spatial technologies for the representation of characteristic of particular place. Over the last decade, researchers use this method to integrate the local knowledge of community within a GIS and Society conceptual framework. Participatory GIS are tailored to answer specific geographic questions at the local level and their modes of implementation vary considerably across space, ranging from field-based, qualitative approaches to more complex web-based applications. These broad ranges of techniques, PGIS are becoming an effective methodology for incorporating community local knowledge into complex spatial decision-making processes. The objective of this study is to reduce the soil erosion by formulating the general rule for the soil conservation by participation of the stakeholders. The poster was prepared by satellite image, topographic map and Arc GIS software including the local knowledge. The data were collected from the focus group discussion and the individual questionnaire for incorporate the local knowledge and use it to find the risk map on the basis of economic, social and manageable physical factors for the sensitivity analysis. The soil erosion risk map is prepared by the physical factors Rainfall-runoff erosivity, Soil erodibility, Slope length, Slope steepness, Cover-management, Conservation practice using RUSLE model. After the comparison and discussion among stakeholders, researcher and export group, and the soil erosion risk map showed that socioeconomic, social and manageable physical factors management can reduce the soil erosion. The study showed that the preparation of the poster GIS map and implement this in the watershed area could reduce the soil erosion in the study area compared to the existing national policy.
\end{abstract}




\section{INTRODUCTION}

Soil erosion is a complex various natural process, which results decrease in fertility of the land and reduction of crop yields. Erosion is very high in Asia, Africa and South America averaging 30-40 t ha-1 year $^{-1}$ (Borrow 1991). The world's natural resources and ecological problems are threatened by erosion. About $25 \times 10^{9} \mathrm{t}$ of soil are eroded into seas every year by surface run off and $6 \times 10^{6}$ ha of productive agricultural land is deserted in world (Anonymous, 200). After the long process soil is formed. Physical, chemical and biological activities have been easily eroded and supply of sediment by the change of land use pattern such as deforestation and agricultural activities in the upper catchments, development of floodplains, urbanization in lower catchments. Sediment load effects on water quality degradation, loss of primary production and benthic habitats. It increase in flooding and an increased cost associated with removal of sediment in navigation channel and with shortening the economic life of hydraulic structures (woods, 1984; Pringle1986; Kinsey1990; Robertson and Lee Long, 1990; Edwards, 1991; Arakel et al., 1993; Arakel 1995; Erskine and Saynor 1996a, 1996b; Erskine, 2003).

The soil erosion is the natural process of combination of historical and geomorphological analysis. The rate of spatial and temporal distribution of the soil erosion depends on the interaction of physical and human circumstances. The land degradation stems from a combination of changes in land use, agricultural intensification and intense rainstorms. Erosion may also be exacerbated in the future in many parts of the world because of climatic change towards a more vigorous hydrologic cycle (Amore et al., 2004).

Phewa lake watershed territory consists of acidic, moderately fine textured and non-stony clay (LRMP, 1983). Colluvial deposits can exceed $15 \mathrm{~m}$ in the depth owing to the mass movement near Pame (Ramsay, 1985). Soils with loamy skeletal texture are found in hilly areas (Mulder, 1978). Sand, silt and clay are found in the area. Bright reddish, dark reddish, brawn and dark brawn soils are found in the different parts of the Phewa lake watershed area (Lamichhane, 2000). The results estimated annual sedimentation deposit in whole Phewa Lake varies from 175,000 to $225,000 \mathrm{~m}^{3}$.

A growing world population and the abandonment of large areas of the formerly productive land as a result of erosion, salinization or alkalization which is the conventional wisdom favors explaining erosion as a response to increasing pressure on the land. The previous study shows that about 5 decades time period half of the area of the Phewa Lake converted into land. There is the severe problem of changing lake into land due to the rainfall, climate change, pollution, sedimentation and land encroachment and other human activities.

Phewa Lake is in mesotrophic situation and going to on state of eutriphication due to the environmental hazards and sedimentation. The lake is sediment eroded from debris of the Harpan Khola, Andheri Khola and its tributaries. From the hilly region of its watershed has the problem of flood and landslide due to the deforestation. Therefore, the study of the lake in climate change, sedimentation and environmental perspective study is essential. The previous study deals with the one or two related issues in soil erosion, sedimentation with some observation and modeling but not integrating participatory GIS approach for the generation of rule and policy as well as the activities of the all stockholder's of the watershed area. This study includes this approach for the reduction of the soil erosion in the watershed area. The objectives of this study is locate the erosion hot spots and land slide effects on soil erosion and sedimentation, to find out the ratio of soil erosion and sedimentation that has been the process of lake converted into land, to find the effects of climate change in soil erosion and sedimentation 


\section{METHODS}

\subsection{Study area}

The Phewa lake watershed area is located in the south-west corner of the Pokhara valley $\left(28^{0} 7^{\prime}\right.$ $\mathrm{N}$ to $28^{\circ} 12^{\prime} \mathrm{N}$ latitude and $84^{\circ} 5^{\prime} \mathrm{E}$ to $84^{\circ} 10^{\prime} \mathrm{E}$ Longitude) which lies on a relative subsidence zone between the greater Himalaya and Mahabharat range. This watershed is spread fully or partially of six VDCs (Sarangkot, KaskiKot, Dhikurpokhari, Bhadaure Tamagi, Chapakot and Pumdi Bhumdi) and the southwestern part of the Pokhara submetropolitan city of Kaski district. It covers an area of Approximately $123 \mathrm{~km}^{2}$ and the length and width of the east-west oriented watershed is about 17 and $7 \mathrm{Km}$ respectively. The surface area of the Phewa Lake is $4.43 \mathrm{~km}^{2}$ and depth from $8.6 \mathrm{~m}$ to $19 \mathrm{~m}$. The watershed height varies from lower part from sea level $793 \mathrm{~m}$ to the upper part $2508 \mathrm{~m}$. The mean annual rainfall in the study area for the past 10 years from 2001 to 2010 is $4325.75 \mathrm{~mm}$. More than $80 \%$ of the annual rainfall occurs during the monsoon season in the months of June to September. The months from October through May are generally very dry season. The study area is the representation of the hill region of Nepal. The study area has the scattered settlement with different casts.

\subsection{Survey methods}

Socio economic data were obtained from the village profile of village development committee report published in 2010 and the questionnaire survey carried out from the different stakeholder's from the watershed area. The report of the village profile contained data of whole study area of the Phew watershed including the number of house, the number of families, income of the families, land use and land cover in the study area. The questionnaire survey was conducted to evaluate the impact of soil erosion due to the socio economic, climatic and anthropogenic factors. 310 questionnaires were collected from the 14-sub watershed area of stakeholders like farmers, mothers' group, teachers, social workers, NGO/GO officers, politicians, students etc. The data collected was based on individual interviews, focus group discussion key informant interviews and field observation method were using questionnaire to investigate for the socio-economic and climatic and anthropogenic factors. The primary information derived from the questionnaire surveyed was climatic, anthropogenic and socioeconomic factors. Garmin GPS collected GPS points of the household. The collected points were projected to the map of the study area. Data on average rainfall, humidity and temperature were collected from the relevant government agencies and meteorological department government of Nepal. These climatic data were compared with soil erosion of the study area.

Primary data were collected from a field survey. A structured questionnaire composed of 12 Variables, all potentially influencing for the soil erosion were designed to obtain the information from the personal interview and discussion with all types of stakeholders'. The questionnaire collected data about the soil erosion details were interviewed.

Secondary data including demographic information about the Phewa watershed area such as rainfall, temperature and the list of soil erosion from the watershed area were analyzed. The soil erosion data were collected from the Government office NGO and the village development committees. The broad structured questionnaires were used for the personal, social, economical, resources management, climatic and participatory approach for soil conservation practices. Additional qualitative information such as change in soil conservation practices, role of local level institution initiation, land management practices six focus group discussions in six VDC, 12 key informant interviews and through the observation of the watershed. Focus group discussions were conducted between the stakeholders' farmer, teacher, politician, mothers' group member and NGO/GO officers, students. A checklist was prepared for the discussion, a researcher was facilitated in 
discussion, and trained note taker noted the issues.

\subsection{Determination of Samples}

Out of 5395 households $(\mathrm{HH})$ in the watershed 310 household $(\mathrm{HH})$ were selected following systematic random sampling methods for personal interview. The samples were selected from the 14 sub watershed according to the house hold population and the representation of all stakeholders. Data were taken from all 14 sub watershed area for the representation of the participatory approach from all stakeholders' and watershed area proportionally.

\subsection{Data analysis methods}

Quantitative data from the personal interviews as processed on the Statistical Package for Social Science (SPSS) frequency table were generated for the general information. Chisquare tests were applied to analyzed categorical data. Correlation were used to identify inter dependence among various factors influencing the soil erosion .Binary logistic regression as applied to find the degree of relationship between independent and dependent variables influencing the soil erosion and conservation practices. Qualitative information collected from focus group and key informants' surveys was processed manually and used in analysis to the complement of quantitative information. The risk of the soil erosion and landslide is mapped by participatory GIS i.e. mapped into the topographic map and later it as prepared on ARC GIS 9.3 software. The analysis was due to the physical factors like compaction, slope, nature of the soil and conservation practices and anthropogenic factors.

RUSLE model was used to find the soil loss in the Watershed with the help of the physical factors data from the related agencies to find the soil loss tone per year in 14-sub watershed. This soil loss map and the PGIS mapped for the hot spot soil erosion were compared and analyzed.

\section{RESULT AND DISCUSSION}

This section was divided into two parts. The first part discusses mainly the descriptive analysis regarding to socio economic characteristics of all types of stakeholders' perception for the soil erosion reduction factors on the watershed area. In the second part climatic and physical factors which affects for soil erosion.

\subsection{Socioeconomic characteristic of stakeholders' and their participation on soil erosion management}

The socio economic condition (income, land holding size and education) of the household head was significantly different between the stakeholders' farmers, mothers' group, teacher, student, businessperson, NGO/GO officer politicians for the participation on soil erosion reduction management. All the educated stakeholders were conscious as compared to uneducated stakeholders on soil erosion issue which effect on Phewa watershed area.

\subsection{Participatory GIS mapping for soil erosion risk area}

Stakeholders' discussion on the focus group the soil erosion spot was traced out by the topographic map and latter analyzed and digitized on ARC GIS 9.3 software for the location of hot spot for soil erosion. The focus group discussion pointed out for the soil erosion factors like climate change effects and lack of the management of the appropriate plantation, types of soil, slopes, deforestation, conservation practices and land covers.

\subsection{Factors motivating the stakeholders for the soil erosion}

Stakeholders reported five major factors including experience sharing and observation of the field. Soil erosion reduction depends on the slope, appropriate plantation, conservation of the forest, construction of the check dams and awareness about the climate change effects. 


\subsection{Social factors}

Social factors like classification of the caste and different groups of stockholder's effects the soil erosion conservation participation. This study reveals that Brahmin and Chhetri (higher caste) with their high social status have more opportunity to interact and have a good plot of farmland than the lower caste. The lower caste stakeholder's have generally steep slopes and problem oriented land. Economically poor stakeholder cannot participate for the reduction of soil erosion due to the economic and lack of awareness and they are diminishing trend from the farm. The higher class people children has trend to go higher education and go for jobs so the trend of decreasing manpower for the farming also create a problem for soil erosion management. The conservation practice reduces due to these reasons so that the soil erosion is increasing.

\subsection{Family Member Occupation}

Nuclear and Joint family systems are in rural area of Nepal. Off farm employments of the family members in a joint family system employed in the local area as teacher or extension workers, significantly influenced the soil erosion management. The soil erosion reduction management is higher in those family members who are employed in a farm occupation. A higher level of family income also increases the ability to bear the risk associated with soil erosion management. Nowak (1987) found that the farmers it's off farm income have grater flexibility to invest in soil conservation new technology compared with farmers who have to rely solely on farm income. There is negative impact of soil erosion reduction management those family members who are employed in Abroad. The family members have leaved the farming occupation their land is not in conservation. Therefore, it increases the soil erosion process naturally.

\subsection{Institutional factors}

Membership in farmers group, cooperatives, mothers group had positive impacts in the soil erosion reduction. The members were participate monthly meeting, share experience, discussion about the problem of soil erosion and landslide on their farmland located in the sub watershed. The farmers were discuss about the socio economic development and remedial solution worked out at the local level.

\section{CONCLUSION}

The findings of this study have important policy implication for the soil erosion reduction by participation of all the stakeholders. The soil erosion hot spot is mapped by the stakeholder who helped for the conservation of the soil in watershed. Stakeholders know the physical factors affecting for the soil erosion are slope, type of the soil and conservation practices. The result of the correlation and regression model showed that the soil erosion reduction is significantly influenced by education farm size and family member occupation and membership on the groups like Cooperative, mothers group and forest group. The RUSLE model had showed the soil loss spot which was somehow similar to the participatory GIS map prepared by the stakeholder's focus group discussion. The generic rule for the finding technical and policy support to the stakeholder and their participation on the mapping make clear concept factors affecting for soil erosion and their participation makes the sustainable soil erosion reduction in Phewa watershed.

\section{Reference:}

Arakel, A.V., 1995. Towards Developing Sediment Quality Assessment Guidelines for Aquatic System: An Australia Perspective. Aust. J. Earth Sci. 42, pp.335-369.

Arakel , A. V. , Loder T., McConchie D., and Paille, C.,1993. Environmental Consequences of Land Degradation in 
Coastal Drainage Basins of North Queensland, Australia: Influence of Farming Practices. Land Degrad. Rehabilit, 4, pp. 99-112.

Barrow C.J., 1991. Land degradation. Cambridge University Press, Cambridge

Edwars, K. Soils Formation and Erosion Rates in Soils, Their Properties, and Management, Ed. by P. E. V.Charman and B. W. Murphy (Sydney Univ. Press, Melbourne, 1991), pp. 36-47

Erskine W. D., and Saynor M. J., 1996. The influence of Waterway Management on Water Quality with Particular Reference to Suspended Solids, Phosphorus, and Nitrogen, Wangaratta

Erskine, W. D., 1985. Downstream Geomorphic Impacts of Large Dams: the Case of Glenbawn Dam, New South Wales, Appl. Geogr. 5, pp.195210.

Ives, J.D., Messerli B., 1989. The Himalayan dilemma: reconciling development and conservation. Routledge, London

JICA/SILT, 2002. Conservation

Development study on the environmental conservation of Phewa Lake in Pokhara, Nepal. Final report submitted by SILT Consultants to JICA/ Nepal, Kathmandu.

Jose,C.S., Das, D.C. 1982. Geomorphic prediction models for sediment production rate and intensive properties of watershed in mayurakshi catchments, in: proceedings of the international symposium on hydrological aspects of mountainous watershed held at school of hydrology, university of Roorke, pp 15-23.

Khanal, T.R.,Bastola, K.R , 2005. The

Himalayan Geographers, volume $4 \& 5$, pp. 17-26.

Misra N., Satyanarayana T., Mukherjee, R.K., 1984. Effects of topo elements on the sediment production rate from sub watersheds in upper Damodar valley .J Agr Eng (ISAE) 21(3), pp. 6570conservation technologies: economic and diffusion explanations. Rural Sociology 42:208-220.

Nowak, P.J., 1987. The adaptation of

Conservation technologies: economic and diffusion explanations. Rural Sociology 42 pp.208-220

Lamichhane, D.B., 2000. Phewa Lake

Watershed Area: settlement and environmental Appraisal pub.

K.B.Lamichhane, lakeside, Baidam, Pokhara, Nepal

Pokharel, S. conservation of Phewa Lake of Pokhara, Nepal

Pringle A. W., 1986.Causes and Effects of Changes in Fluvial Sediment yield to The North-East Queensland Coast, Australia, Ed. D. Hopley Townsville.

Robetson, A. and Lee Long W., 1990. The influences of Nutrient and Sediment Loads on Tropical Mangrove and Sea grass Ecosystems," in Proceedings of the Workshop on Land Use Patterns and Nutrient Loading of the Great Barrier Reef Region, Townsville, 1990, Ed. by D. Yellowlees. pp. 197-209.

Woods L., 1984.Land Degradation in Australia Australian Government Publishing service, Canberra 